\title{
Modeling Regional Soil Water Balance in Farmland of the Middle Reaches of Heihe River Basin
}

\author{
Jiang $\mathrm{Li}^{1,2}$, Xiaomin Mao ${ }^{1, *}$, Songhao Shang ${ }^{2}$ (iD and Tammo S. Steenhuis ${ }^{3}$ \\ 1 Centre for Agricultural Water Research in China, College of Water Resources and Civil Engineering, \\ China Agricultural University, Beijing 100083, China; lijiang2017@mail.tsinghua.edu.cn \\ 2 State Key Laboratory of Hydroscience and Engineering, Department of Hydraulic Engineering, \\ Tsinghua University, Beijing 100084, China; shangsh@tsinghua.edu.cn \\ 3 Department of Biological and Environmental Engineering, Riley-Robb Hall, Cornell University, \\ Ithaca, NY 14853, USA; tss1@cornell.edu \\ * Correspondence: maoxiaomin@cau.edu.cn; Tel.: +86-10-6273-8498
}

Received: 12 September 2017; Accepted: 31 October 2017; Published: 3 November 2017

\begin{abstract}
Quantifying components of soil water balance in farmland of the middle reaches of Heihe River Basin is essential for efficiently scheduling and allocating limited water resources for irrigation in this arid region. A soil water balance model based on empirical assumptions in the vadose zone of farmland was developed and simulation results were compared/validated with results by the numerical model HYDRUS-1D. Results showed a good coherence between the simulated results of the water balance models and the HYDRUS-1D model in soil water storage, evapotranspiration, deep percolation and groundwater recharge, which indicated that the water balance model was suitable for simulating soil water movement in the study area. Considering the spatial distribution of cropping patterns, groundwater depth and agricultural management, ArcGIS was applied for the pre-/post-processing of the water balance model to quantify the spatial distribution of components of soil water balance in the major cropland in middle reaches of Heihe River Basin. Then, distributions of components of soil water balance in the major cropland under different water-saving irrigation practices during the growing season were predicted and discussed. Simulation results demonstrated that evapotranspiration of the main crops would be more prominently influenced by irrigation quota under deep groundwater depth than that under shallow groundwater depth. Groundwater recharge would increase with the increase of irrigation quota and decrease with the increase of groundwater depth. In general, when groundwater depth reached $3 \mathrm{~m}$, groundwater recharge from root zone was negligible for spring wheat. While when it reached $6 \mathrm{~m}$, ground water recharge was negligible for maize. Water-saving irrigation practices would help to reduce groundwater recharge with a slight decrease of crop water consumption.
\end{abstract}

Keywords: water balance model; HYDRUS-1D; soil water balance; ArcGIS; Heihe River Basin

\section{Introduction}

Quantifying the components of soil water balance in farmland is essential in arid regions with limited water resources. It can provide a basis for efficient irrigation scheduling and optimum water resource allocation [1-5].

Soil water balance in the vadose zone of farmland would be influenced by water-saving irrigation practices. The main components of soil water balance in farmland mainly include irrigation/precipitation, surface runoff, evaporation, transpiration, water exchange between root zone and the lower zone, variation of soil water storage, and lateral seepage to adjacent land [6,7].

Field experiments have been widely conducted to quantify soil water balance in farmland [8-13]. Weighing lysimeters, eddy covariance and Bowen ratio systems are frequently used to estimate 
evapotranspiration [14-16]. The variation of the water table is monitored to calculate groundwater recharge [17]. Soil water content measured by neutron probe, time-domain reflectometer, or oven drying is usually used to obtain soil water storage [18]. However, experiments are expensive, time-consuming and site specific. Thus, simulation models were established to predict soil water content and calculate the transformation of water input in a farmland vadose zone [19-24]. Hydrodynamic models and water balance models are two main types of models for simulating soil water movement $[25,26]$.

Hydrodynamic models for vadose zones are based on the Richards equations combining mass conservation and Darcy's law $[27,28]$. These models have sound physical bases and can describe detailed soil water movement. One of popular hydrodynamic models is HYDRUS-1D [29,30]. Soil water balance models are based on the concept of mass balance, which consider the total soil water quantity into and out of the target zone [31,32]. These models are widely used in agricultural water management because they perform as well as hydrodynamic models and require less input parameters and can be easily used at field scale [33-35].

For irrigated farmland on regional scales, especially for the arid zone, large spatial variation of soil texture, irrigation and groundwater exists, which leads to differences in the soil water balance of the root zone $[36,37]$. Because of scale-matching problems, hydrological models were usually achieved by using a regional groundwater flow model with the rough estimation of evapotranspiration on land surface [38], or by the coupling of several models, e.g., Modflow and SWAP [39], Modflow and HYDRUS [40]. Most of the hydrodynamic models for a vadose zone are applied at point or field scale. Because of excess the computer time and detailed subsoil characteristics required, those models cannot be applied at regional scale where spatial variability in crop, soil and irrigation practices should be included $[41,42]$. Only when vadose water balance models can be up-scaled to a regional scale can the full impacts/benefits of this kind model be realized in irrigated farmland [43,44]. Geographic Information Systems (GIS) can be used to extend vadose applications to the regional scale through loose, close or embedded coupling.

Previous studies on GIS-coupled models usually focused on certain areas and the purpose of them was always to simulate the runoff or groundwater balance. For example, Wang et al. [45] used GIS with T-M water balance model to calculate the water balance and obtained the runoff in the Jinyangchuan watershed. Portoghese et al. [46] and Tilahun and Merkel [47] coupled GIS with water balance models and calculated groundwater balance. In arid zones, there are no quantities of surface runoff produced by rainfall like there are in humid areas. In these regions, most of the water recourses are used for agriculture and water is usually diverted from canals/rivers to farmland, and consumed largely by evaporation/transpiration. Under these conditions, the most popular hydrological models, which are good at simulating surface runoff processes, such as SWAT, SHE, VIC model, etc., should be improved or modified when used in such regions [48]. Especially when water-saving practices are taken in this region, the hydrological processes would be influenced by human control. Therefore, it is necessary to develop some models that are specifically suitable for these regions.

For this purpose, in this study we proposed a field scale soil water balance model which requires fewer parameters and less computer time/memory than the commonly used soil water dynamic models, e.g., HYDRUS-1D. It can be easily integrated into GIS for regional scale quantifications. Then this method was applied in the middle reaches of Heihe River Basin, to investigate the impacts of water-saving irrigation practices on the soil water balance of farmland. First, the soil water balance model was evaluated by comparing with those simulated by HYDRUS-1D. Then, the model was loosely coupled with ArcGIS for the pre-/post-processing for regional-scale calculations. Finally, the soil water balance in the vadose zone is discussed under different groundwater depths with various water-saving irrigation practice applications. 


\section{Materials and Methods}

\subsection{Study Area and Data Collection}

The study area is the middle reaches of Heihe River Basin, which is located in the arid region of northwest China and covers 17 irrigation districts. Figure 1 shows the distribution of landscape units in this area, including the main crops, forest, grassland, bare soil and surface water, which were obtained from land use map and cropping patterns based on remote sensing data from the Western Database (http://www.heihedata.org/). The study area is $6736 \mathrm{~km}^{2}$ consisting of $38 \%$ farmland, $14 \%$ forest/grass land, $4 \%$ river and flood plain, and $41 \%$ bare soil. Most of the cultivated lands were planted with maize and spring wheat, which accounted for over $50 \%$ of the farmland. The other crops include barley, interplant of spring wheat and maize (relay strip interplant in this region for the purpose of improving crop economic production in this region), and others (mainly various kinds of vegetables). The intensive planting area is distributed in the southern and middle irrigation districts. Table 1 shows the classification of soil texture based on our survey in 2014, which demonstrated that in most areas it is loam at $0-100 \mathrm{~cm}$ soil layer, and loam, sand or cobble stone in deep layers. Therefore, the soil types are grouped into three types (T1, T2 and T3) and locations are shown in Figure 1.

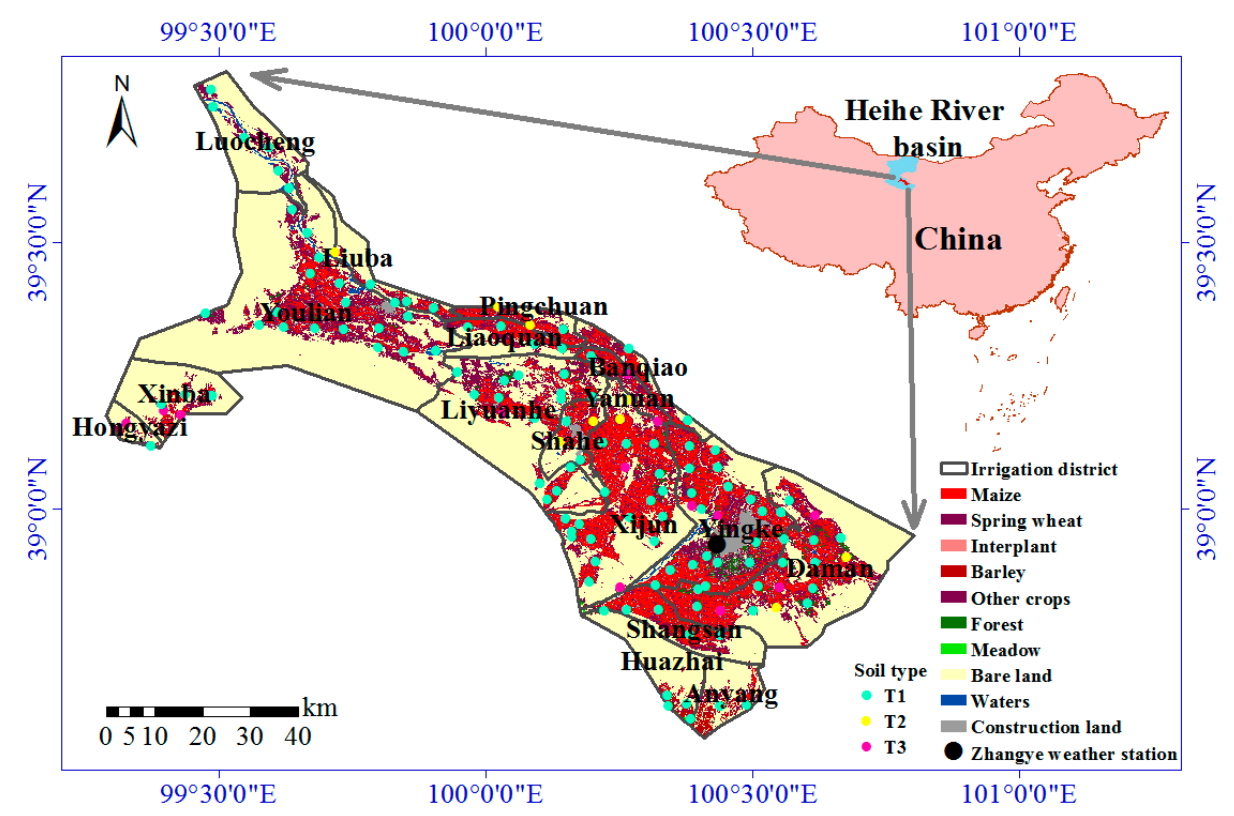

Figure 1. Geographic locations, land use and crop patterns in the study area.

Crop growth in the study area mainly relies on irrigation, and agricultural irrigation generally takes over $90 \%$ of the total water resources, with over $85 \%$ of the irrigation water coming from the Heihe River [49]. With the implementation of the Water Diversion Plan [50], the amount of water diverted from the Heihe River to the middle reaches of the basin has reduced by one-third since the year 2001. Table 2 shows the statistics of irrigation depths for the main crops in each irrigation districts during the year 2000 to 2010 . It can be seen that irrigation depth for maize is normally higher than that for spring wheat. There are big differences between irrigation depths for the same crop in different irrigation districts. In the same irrigation district, the main crop usually has a big variation of irrigation amounts because of climate or human factors. 
Table 1. Results of soil survey on the layered soil samples.

\begin{tabular}{cccc}
\hline \multirow{2}{*}{ Soil Type } & $\mathbf{0 - 1 0 0} \mathbf{~ c m}$ & $\mathbf{1 0 0 - 1 4 0 ~} \mathbf{~ m}$ & Number of Sample Sites \\
\cline { 2 - 3 } & \multicolumn{2}{c}{ Soil Texture } & 11 \\
T1 & Loam & Loam & 4 \\
T1 & Loam & Sandy loam & 12 \\
T1 & Loam & Silt loam & 1 \\
T1 & Loamy sand & Silt loam & 1 \\
T1 & Loamy sand & Sandy loam & 6 \\
T1 & Sandy loam & Loam & 12 \\
T1 & Sandy loam & Sandy loam & 6 \\
T1 & Sandy loam & Silt loam & 7 \\
T1 & Silt loam & Loam & 2 \\
T1 & Silt loam & Sandy loam & 57 \\
T1 & Silt loam & Silt loam & 4 \\
T2 & Loamy sand & Sand & 4 \\
T2 & Sandy loam & Loamy sand & 3 \\
T2 & Sandy loam & Sand & 1 \\
T2 & Silt loam & Loamy sand & 2 \\
T3 & Loam & Cobble stone & 12 \\
T3 & Sandy loam & Cobble stone & 14 \\
T3 & Silt loam & Cobble stone & \\
\hline
\end{tabular}

Table 2. Basic statistics of irrigation depths for the main crops in different irrigation districts (unit: $\mathrm{mm}$ ).

\begin{tabular}{ccccccc}
\hline \multirow{2}{*}{ Irrigation District } & \multicolumn{2}{c}{ Irrigation Depths for Spring Wheat } & \multicolumn{2}{c}{ Irrigation Depths for Maize } \\
\cline { 2 - 6 } & Minimum & Maximum & Average & Minimum & Maximum & Average \\
\hline Daman & 369 & 545 & 443 & 495 & 698 & 612 \\
Yingke & 417 & 519 & 465 & 603 & 738 & 686 \\
Xijun & 449 & 551 & 509 & 561 & 729 & 629 \\
Shangsan & 462 & 560 & 514 & 557 & 810 & 669 \\
Anyang & 480 & 561 & 513 & 228 & 600 & 484 \\
Huazhai & 222 & 405 & 342 & 375 & 608 & 479 \\
Pingchuan & 540 & 675 & 620 & 623 & 1155 & 776 \\
Banqiao & 480 & 750 & 671 & 623 & 1080 & 875 \\
Yanuan & 540 & 780 & 698 & 623 & 975 & 897 \\
Liaoquan & 533 & 705 & 670 & 810 & 1184 & 928 \\
Shahe & 432 & 600 & 530 & 629 & 900 & 785 \\
Liyuanhe & 432 & 660 & 496 & 629 & 842 & 697 \\
Youlian & 543 & 615 & 586 & 819 & 975 & 919 \\
Liuba & 510 & 615 & 578 & 788 & 1028 & 935 \\
Luocheng & 495 & 630 & 582 & 840 & 990 & 905 \\
Xinba & 525 & 675 & 587 & 675 & 975 & 797 \\
Hongyazi & 488 & 684 & 587 & & & \\
\hline
\end{tabular}

The middle reaches of the Heihe River basin have temperate arid climate with the mean annual temperature varying from $0{ }^{\circ} \mathrm{C}$ to $5{ }^{\circ} \mathrm{C}$. Meteorological data, i.e., precipitation, relative humidity, sunshine hours, average temperature, minimum air temperature, maximum air temperature and wind speed at Zhangye weather station $\left(38^{\circ} 56^{\prime} \mathrm{E}, 100^{\circ} 26^{\prime} \mathrm{N}, 1482.7 \mathrm{~m}\right)$ were obtained from China Meteorological Data Sharing Service System (http:/ /cdc.nmic.cn/home.do). Figure 2 shows the annual precipitation and reference evapotranspiration from the year 2000 to 2014 at Zhangye weather station. Obviously the annual precipitation is below $250 \mathrm{~mm}$ and the annual reference evapotranspiration is above $1000 \mathrm{~mm}$. The average groundwater level is in the range of $1300 \mathrm{~m}$ to $1690 \mathrm{~m}$ above mean sea level. 


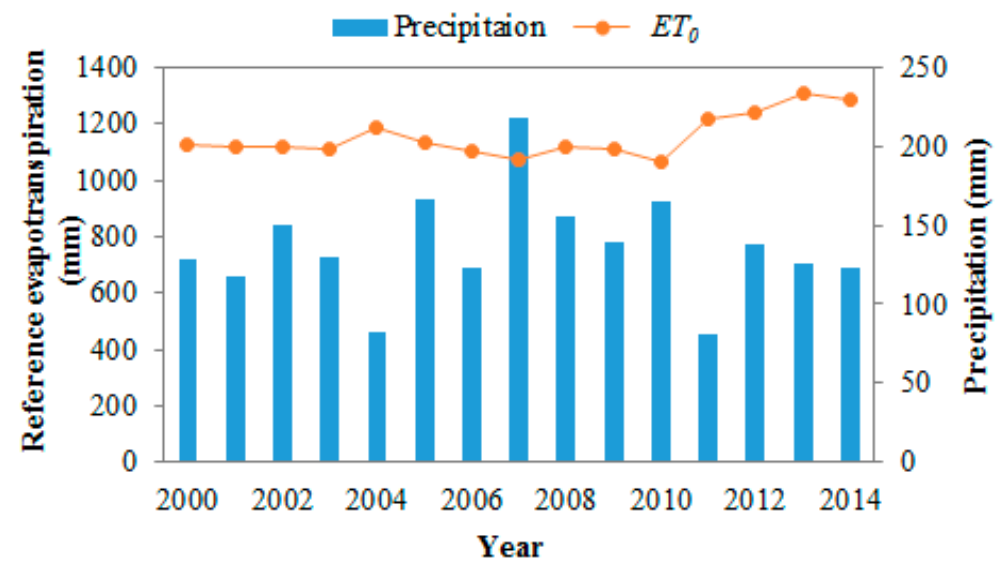

Figure 2. Annual reference evapotranspiration and precipitation in the study area during the year 2000 to 2014.

\subsection{Model Description and Related Parameters}

\subsubsection{Water Balance Models in Vadose Zone}

To quantify crop water consumption, deep percolation from root zone and groundwater recharge in farmland, we developed a corresponding soil water balance model [51], which is similar to the previous study [52]. The model was briefly illustrated here. The vadose zone is divided into two parts in vertical direction, i.e., root zone (from $0 \mathrm{~m}$ to $1 \mathrm{~m}$ below ground surface) and buffer zone (from $1 \mathrm{~m}$ below soil surface to groundwater level, because groundwater table depth is generally greater than $1 \mathrm{~m}$ in the farmland of the study area). Figure 3 shows the water balance in the vadose zone of farmland.

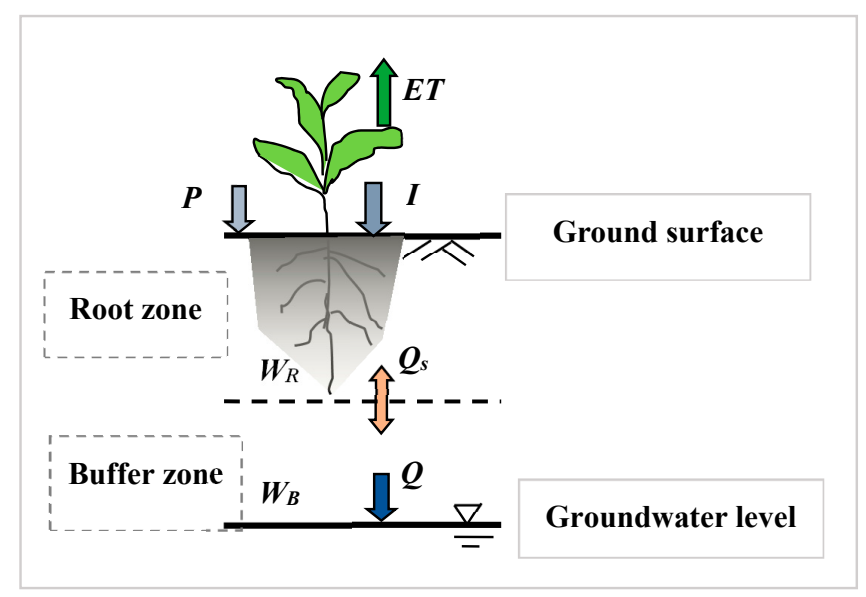

Figure 3. Water balance in vadose zone of farmland.

In root zone, water balance can be described by [53]

$$
\Delta W_{R}=\left(P+I-E T-Q_{s}\right) \cdot \Delta t
$$

where $\Delta W_{R}$ is the changes of water storage in root zone $(\mathrm{mm})$ (positive means increase), $\Delta t$ is time step (day), $P$ is precipitation ( $\mathrm{mm} /$ day), $I$ is irrigation depth (mm/day), ET is evapotranspiration (m/day), and $Q_{s}$ is flux (called percolation here) between root zone and buffer zone (mm/day). $Q_{s}$ can be calculated by Equation (2) [54].

$$
Q_{s}=a \cdot\left(\frac{W_{R}}{W_{R f}}\right)^{b} \cdot\left(W_{R}-W_{R c}\right)
$$


where $W_{R}$ is the actual water storage in root zone $(\mathrm{mm}), W_{R f}=\theta_{f} \cdot L_{R}$ is the field water capacity of root zone, $\theta_{f}$ is soil water content at field capacity $\left(\mathrm{mm}^{3} / \mathrm{mm}^{3}\right)$ and is set as 0.25 for loam [55], $L_{R}$ is the depth of root zone $(\mathrm{mm}), W_{R c}$ is the critical value of water storage for water exchange with buffer zone, which is related with field water capacity and groundwater table depth, and usually considered to be constant when groundwater table depth is great. $a$ and $b$ are empirical coefficients (dimensionless), which are related with soil texture and set as 0.11 and 2.5, respectively [56]. Note that $Q_{s}>0$ indicates deep percolation, while $Q_{s}<0$ means upward recharge from buffer zone to root zone.

$E T$ is determined by crop types, growing seasons, atmosphere condition and soil moisture status [57], which is

$$
E T=K_{s} \cdot K_{c} \cdot E T_{0}
$$

where $E T_{0}$ is reference evapotranspiration ( $\mathrm{mm} /$ day) and can be calculated by the Penman-Monteith equation recommended in Allen et al. [57]. $K_{c}$ is crop coefficient (dimensionless), which varies with specific crop characteristics and growing stage, and is normally obtained through field experiments. The values of $K_{c}$ for typical crops are obtained according to previous research in the study area [58]. $K_{s}$ is soil water stress coefficient (dimensionless) and can be described by Equation (4) [59]:

$$
\begin{aligned}
K_{s} & =\frac{\ln \left(A_{w}+1\right)}{\ln 101} \\
A_{w} & =\frac{\theta-\theta_{w}}{\theta_{f}-\theta_{w}} \times 100
\end{aligned}
$$

where $\theta=W_{R} / L_{R}$ is the average soil water content in root zone $\left(\mathrm{mm}^{3} / \mathrm{mm}^{3}\right)$, and $\theta_{w}$ is wilting soil water content $\left(\mathrm{mm}^{3} / \mathrm{mm}^{3}\right)$, which was set as 0.09 for loam [60] in this study.

The buffer zone or the area between root zone and groundwater, we assume that it had water connection with root zone through $Q_{s}$ and the surplus water in this zone would recharge to groundwater. Groundwater table depth in most area of the study region is over $3 \mathrm{~m}$. Hence, the phreatic evaporation, i.e., the upward flux from groundwater to root zone, is negligible $[61,62]$. The water balance and related terms can be calculated from.

$$
\begin{gathered}
\Delta W_{B}=\left(-Q+Q_{s}\right) \cdot \Delta t \\
\text { If } W_{B}+Q_{S}>W_{B f}, Q=W_{B}+Q_{S}-W_{B f} \\
\text { If } W_{B}+Q_{S}<W_{B f}, Q=0
\end{gathered}
$$

where $\Delta W_{B}$ is the changes of water storage in buffer zone $(\mathrm{mm})$ (positive means increase), $W_{B}$ and $W_{B f}$ are actual water storage and field water capacity of buffer zone $(\mathrm{mm}), Q$ is groundwater recharge per day $(\mathrm{mm})$.

\subsubsection{HYDRUS-1D Model}

HYDRUS-1D is one of hydrodynamics models, which can simulate one-dimensional water transport in variable saturated porous media. This model has been successfully used to simulate water flow in the middle reaches of Heihe River Basin [63-66]. Therefore, in this study, results simulated by HYDRUS-1D were used to validate the calculations of water balance models. The soil water equation in HYDRUS-1D model is the Richards equation

$$
\frac{\partial \theta}{\partial t}=\frac{\partial}{\partial z}\left[K(h)\left(\frac{\partial h}{\partial t}+1\right)\right]-S(h)
$$

where $t$ is time (day), $\theta$ is volumetric water content $\left(\mathrm{mm}^{3} / \mathrm{mm}^{3}\right), h$ is water pressure head $(\mathrm{mm}), z$ is vertical coordinate axis $(\mathrm{mm}), K(h)$ is hydraulic conductivity $(\mathrm{mm} /$ day), and $S(h)$ is water sink term 
(mm/day). The van Genuchten-Mualem (VG-M) equation $[67,68]$ models the variation of $K(h)$ with soil water content where

$$
\begin{gathered}
\theta(h)= \begin{cases}\theta_{r}+\frac{\theta_{s}-\theta_{r}}{\left[1+|\alpha h|^{n}\right]^{m}} & h<0 \\
\theta_{s} & h \geq 0\end{cases} \\
K(h)= \begin{cases}K_{s} S_{e}{ }^{l}\left[1-\left(1-S_{e}^{1 / m}\right)^{m}\right]^{2} & h<0 \\
K_{s} & h \geq 0\end{cases} \\
S_{e}=\frac{\theta-\theta_{r}}{\theta_{s}-\theta_{r}} \\
m=1-1 / n, \quad n>1
\end{gathered}
$$

where $\theta_{r}$ and $\theta_{s}$ are residual and saturated water content, respectively, $K_{s}$ is saturated hydraulic conductivity, $S_{e}$ is effective saturation and $\alpha, n$ and $l$ are empirical coefficients (the inverse of the air-entry value, a pore-size distribution index and a pore-connectivity parameter, respectively).

The sink term $S(h)$ in Equation (9) is actual root-water uptake (equal to actual transpiration), obtained from the Feddes equation [69]

$$
S(h)=\alpha(h) \cdot b(z) \cdot T_{p}
$$

where root-water uptake stress response function $\alpha(h)$ is a prescribed dimensionless function of the soil water pressure head $h(0 \leq \alpha(h) \leq 1), b(z)$ is normalized root-water uptake distribution, and $T_{p}$ is potential transpiration rate.

The potential crop evapotranspiration $\left(E T_{p}\right)$ was obtained from Equation (15) [57]

$$
E T_{p}=E T_{0} \cdot K_{c}
$$

where $E T_{0}$ is reference evapotranspiration ( $\mathrm{mm} /$ day), $K_{c}$ is crop coefficient, which can be obtained from previous study [70].

$E T_{p}$ was then divided into potential evaporation $\left(T_{p}\right)$ and potential transpiration $\left(E_{p}\right)$. This partitioning was achieved using crop leaf area index (LAI) based on Beer Equation [71], where $c$ is empirical parameter.

$$
\begin{gathered}
E_{p}=E T_{p} \times e^{-c \mathrm{LAI}} \\
T_{p}=E T_{p} \times\left(1-e^{-c \mathrm{LAI}}\right)
\end{gathered}
$$

\subsubsection{Model Setup and Input Parameters}

The vadose zone of farmland from ground surface to groundwater level with either maize or spring wheat crop was selected as the simulation domain. Based on observed groundwater depths under farmland, depths to groundwater of $2 \mathrm{~m}, 3 \mathrm{~m}, 4 \mathrm{~m}, 5 \mathrm{~m}$ and $6 \mathrm{~m}$ were used. As seen in Table 1 and Figure 1, most of the soil texture in the study area is T1. Therefore, the common soil type loam was used in HYDRUS-1D for model validation.

The initial condition for HYDRUS-1D model was assumed to be in hydrostatic condition, therefore the soil matric potential decreased with the increase of elevation. Soil water storage of root zone and buffer zone under the initial condition in HYDRUS-1D model was taken as the input to the water balance model for initial conditions. The upper boundary condition for HYDRUS-1D was the atmospheric boundary condition, including precipitation, evaporation and irrigation (with transpiration as the sink term). The lower boundary was at the free surface of groundwater. We assumed that the groundwater level did not fluctuate during the simulation period. So the lower boundary for HYDRUS-1D was set as stable pressure head boundary (pressure head was $0 \mathrm{~m}$ ). The distribution of potential root-water uptake over root zone was derived from potential transpiration, 
where the actual uptake and transpiration would be simulated considering root distribution and soil water condition in root zone. We assumed that the root was uniformly distributed within the underground $1 \mathrm{~m}$ depth (i.e., root zone). The simulation period was 152 days and 123 days for maize and spring wheat, respectively, according to the investigation of local planting custom.

Irrigation schedules commonly used by farmers for maize and spring wheat were obtained from previous study [72] and shown in Table 3. Soil hydraulic parameters for VG-M model and parameters of water stress response function in Feddes model were set as the default values for loam in HYDRUS [29,73]. Values of crop coefficients are from previous research in the same study area and shown in Table 4 [74].

Table 3. Irrigation schedules for maize and spring wheat (DAS means days after sowing).

\begin{tabular}{|c|c|c|c|c|c|c|c|c|}
\hline \multirow[b]{2}{*}{ Crops } & \multicolumn{2}{|r|}{ First } & \multicolumn{2}{|c|}{ Second } & \multicolumn{2}{|r|}{ Third } & \multicolumn{2}{|r|}{ Fourth } \\
\hline & DAS & $\begin{array}{l}\text { Irrigation } \\
\text { Depth }(\mathrm{mm})\end{array}$ & DAS & $\begin{array}{c}\text { Irrigation } \\
\text { Depth (mm) }\end{array}$ & DAS & $\begin{array}{c}\text { Irrigation } \\
\text { Depth (mm) }\end{array}$ & DAS & $\begin{array}{c}\text { Irrigation } \\
\text { Depth (mm) }\end{array}$ \\
\hline Maize & 34 & 160 & 61 & 230 & 90 & 230 & 113 & 230 \\
\hline Spring wheat & 33 & 165 & 61 & 150 & 89 & 150 & & \\
\hline
\end{tabular}

Table 4. Parameters for models.

\begin{tabular}{cccc}
\hline \multicolumn{2}{c}{ Parameters } & Maize & Spring Wheat \\
\hline & $\theta_{r}\left(\mathrm{~cm}^{3} / \mathrm{cm}^{3}\right)$ & 0.005 & 0.005 \\
& $\theta_{s}\left(\mathrm{~cm}^{3} / \mathrm{cm}^{3}\right)$ & 0.4 & 0.4 \\
VG-M model & $a$ & 0.036 & 0.036 \\
& $n$ & 1.56 & 1.56 \\
& $K s(\mathrm{~cm} /$ day) & 24.96 & 24.96 \\
& 1 & 0.5 & 0.5 \\
\hline \multirow{5}{*}{ Feddes model } & $h_{1}(\mathrm{~cm})$ & -15 & 0 \\
& $h_{2}(\mathrm{~cm})$ & -30 & -1 \\
& $h_{3}(h i g h)(\mathrm{cm})$ & -325 & -500 \\
& $h_{3}($ low $)(\mathrm{cm})$ & -600 & -900 \\
& $h_{4}(\mathrm{~cm})$ & -8000 & $-16,000$ \\
\hline \multirow{5}{*}{ Crop coefficients $\left(K_{C}\right)$} & Seeding to Trefoil & 0.43 & 0.48 \\
& Tointing to Heading & 1.32 & 0.76 \\
& Heading to Mature & 1.47 & 1.05 \\
& Heil Jointing & 0.9 & 0.84 \\
\hline
\end{tabular}

\subsection{Methodology of Extending the Local Water Balance Model Simulation Results to Regional Scale}

The soil water balance at the regional scale was obtained by loose coupling between water balance models for each unit and ArcGIS. ArcGIS software was used as a pre-/post-processor to generate and organize the input data as well as display the output data. For details, the spatial distribution of cropping patterns, groundwater depths and agricultural management in the study area were grouped into small units under the ArcGIS by its function of UNION, i.e., for each unit it had the same crop type, groundwater depth range and irrigation schedule. Then, the data files in ArcGIS were transferred into Microsoft Excel. The Excel file was used as the reference to generate the water balance models' input project files. Further, water balance models were run to calculate components of soil water balance for each unit, and the outputs of models were transferred back to the Excel file and then into ArcGIS by the function of JOIN. Lastly, ArcGIS was used to present the spatially distributed simulation results.

\subsection{Scenario Design}

The water balance model was used to simulate farmland soil water movement under different groundwater depths (from $2 \mathrm{~m}$ to $6 \mathrm{~m}$ ) or various irrigation quotas. Irrigation depths ranged from $450 \mathrm{~mm}$ to $1300 \mathrm{~mm}$ for maize and $280 \mathrm{~mm}$ to $750 \mathrm{~mm}$ for spring wheat, respectively. Then, 
regional farmland soil water balance in the major cropland under water-saving irrigation practices in the study area was predicted as deficit irrigation is one of the useful water saving irrigation practices in arid regions.

For regional scales, average irrigation amounts of maize or spring wheat during the years 2000 to 2010 for each irrigation district (shown in Table 2) were selected as the irrigation quotas under the status quo scenario. The irrigation schedule (i.e., times of irrigation, the irrigation days after seeding and the proportion of irrigation amount in each irrigation event) was the same with the irrigation schedule in Section 2.2.3. The irrigation water application were decreased to $80 \%$ and $60 \%$ under the conditions of scenario A and scenario B, respectively. The mean of metrological data at Zhangye weather station during the period from 2000 to 2010 were used in all scenarios (i.e., status quo, scenario A and scenario B).

\section{Results and Discussion}

\subsection{Model Validation}

In this section, HYDRUS-1D model was used to validate water balance models. The results of components of water balance, such as soil water storage, evapotranspiration, deep percolation from root zone to buffer zone and groundwater recharge were compared between these two models.

\subsubsection{Soil Water Storage}

Results of soil moisture in root zone simulated by HYDRUS-1D and water balance model have good agreements (Figure 4). Fluctuations of soil moisture in root zone consistently reflected the irrigation events. Soil moisture increased rapidly after irrigation or precipitation, and then fell down because of deep percolation or evapotranspiration. In the earlier stage of growing period, transpiration rate was relatively small with non-flourished leaves, which led to slowly declined soil moisture. With the growing of crops, the transpiration rate and root-water uptake increased, which lead to a sharper drop of soil moisture in root zone. At the end of crop growing period, soil moisture in the root zone declined slowly because of the small transpiration by withered leaves when crops began to mature.
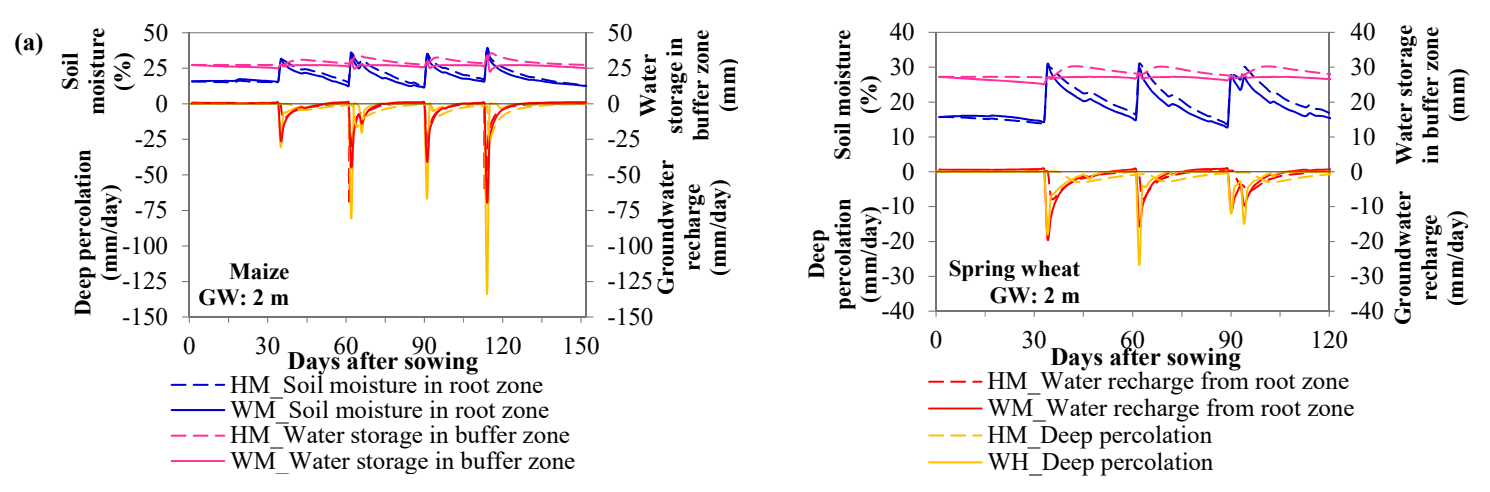

Figure 4. Cont. 
(b)
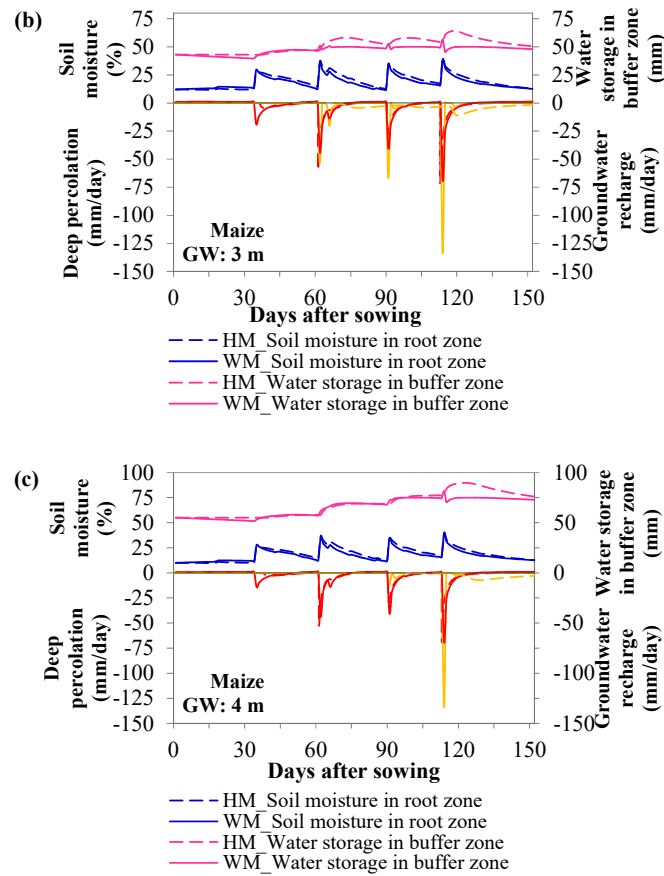

(d)

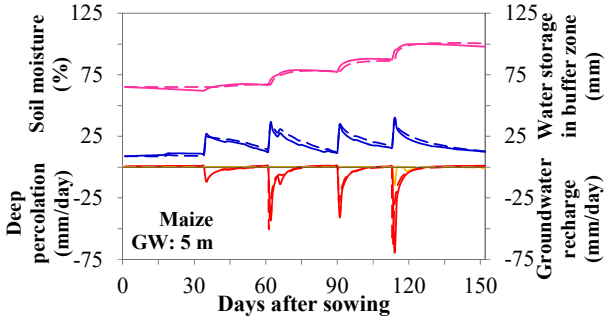
$---\mathrm{HM}$ Soil moisture in root zone
$-\mathrm{WM}$ Soil moisture in root zone - HM Water storage in buffer zon WM Water storage in buffer zon

(e)

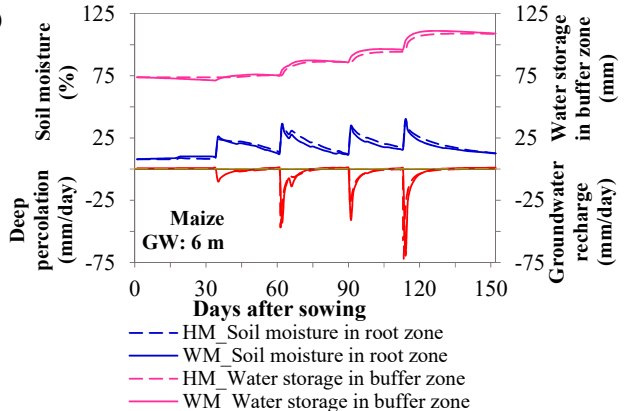

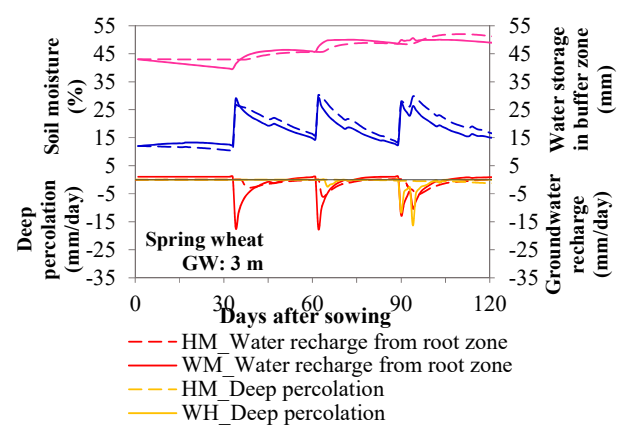
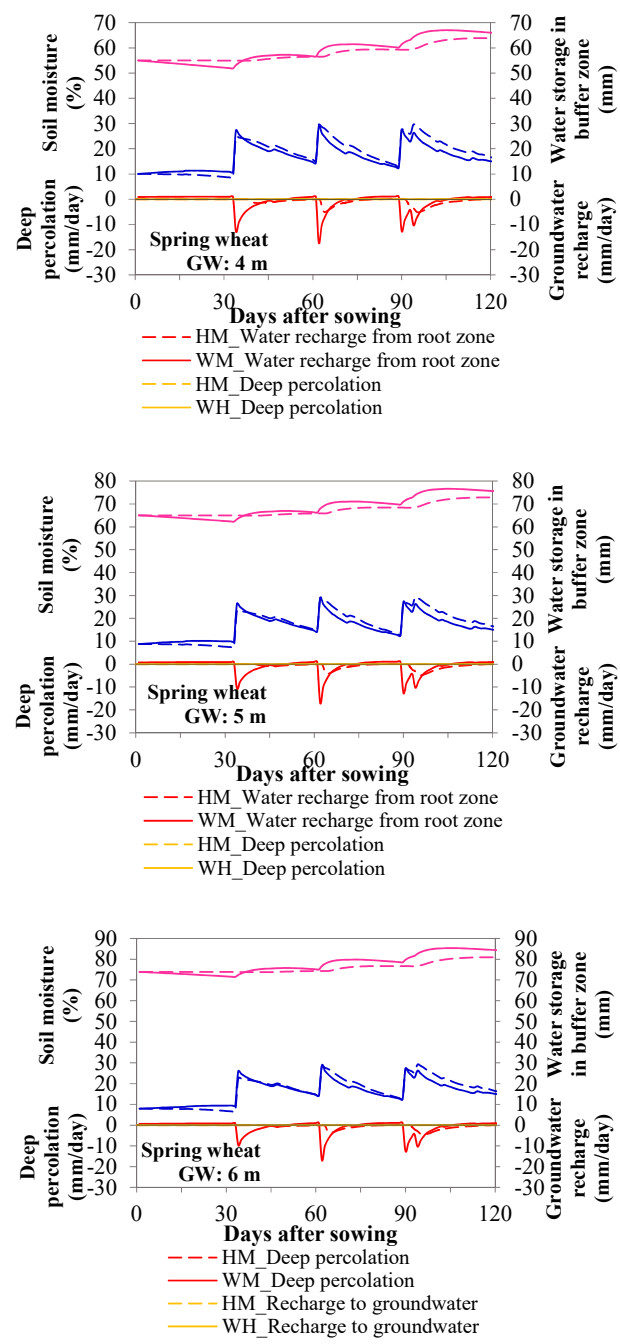

Figure 4. Simulation results of soil moisture, water storage in buffer zone, deep percolation and groundwater recharge for summer maize and spring wheat under the conditions of groundwater depths at $2 \mathrm{~m} \mathrm{(a),} 3 \mathrm{~m} \mathrm{(b)}, 4 \mathrm{~m} \mathrm{(c),} 5 \mathrm{~m}$ (d) and $6 \mathrm{~m}$ (e) (For deep percolation and groundwater recharge, negative values mean downward. HM means the results simulated by HYDRUS-1D, WM means the results calculated by water balance model, and GW means groundwater depth).

Soil moisture in the root zone was relatively low because of less precipitation at the beginning of the crop-growing period, before irrigation. During this period, soil moisture calculated by water balance model was larger than that simulated by HYDRUS-1D. It is possibly because the empirical equation used in the water balance model is not powerful and accurate enough to reflect water stress on root uptake. The discrepancy of results between these two models becomes larger when groundwater becomes deeper. The largest error in moisture content between these two models were $2 \%$ and $3 \%$ for 
maize and spring wheat, respectively. After irrigation, soil moisture in the root zone increased rapidly. The peak values simulated by the water balance model were larger than those by HYDRUS-1D. Results calculated by water balance model were lower than results by HYDRUS-1D during these periods, because the water balance model was more sensitive to groundwater recharge than HYDRUS-1D. At the end of the crop-growing period, soil moisture calculated by these two models was similar.

Soil water storage in the buffer zone calculated by these two models (see Figure 4) after sowing and before harvest was close. Each time, before irrigation, soil in the root zone was dry with relatively low negative soil potential that tended to suck water from the buffer zone. Therefore, soil water storage in the buffer zone declined slowly. After irrigation, soil water in the root zone would increase sharply with water input, and decrease greatly in the first few days by deep percolation. In the water balance model, deep percolation was calculated based on the empirical equation (Equation (2)), where deep percolation would occur when the soil water storage became larger than the critical value of water storage $W_{R c}$. This empirical equation did not consider the feedback of soil water in the buffer zone on deep percolation, while the Richards equation-based models such as HYDRUS-1D would capture this phenomenon, i.e., deep percolation would be hindered with the increase of soil water in the lower soil zone (buffer zone). As a result, the fluctuation of water storage calculated by the water balance model was greater than that by HYDRUS-1D. Despite the differences, the trend of simulation results by the water balance model was similar to those by HYDRUS-1D and the results were in reasonable agreement.

\subsubsection{Evapotranspiration (ET)}

Figure 5 shows the results of evapotranspiration (ET) calculated by these two models under different groundwater depths. ET calculated by these two models had the same trends, which presented as pulsed fluctuations with irregular peak values. The fluctuation of ET was related to the climate and irrigation [75]. ET of both maize and spring wheat decreased with increasing groundwater depth under the same climate and irrigation. The total ET for maize was in the range of $569 \mathrm{~mm}$ to $591 \mathrm{~mm}$ calculated by water balance model and $570 \mathrm{~mm}$ to $578 \mathrm{~mm}$ by HYDRUS-1D (Table 5). As to spring wheat, the total ET was in the range of $401 \mathrm{~mm}$ to $422 \mathrm{~mm}$ calculated by water balance model and $431 \mathrm{~mm}$ to $438 \mathrm{~mm}$ by HYDRUS-1D. The results are consistent with results simulated by the other study in the same region. For example, Zhu [76] obtained that ET for maize was in the range of $496 \mathrm{~mm}$ to $580 \mathrm{~mm}$, whereas for spring wheat it was from $484 \mathrm{~mm}$ to $524 \mathrm{~mm}$ in the Yingke irrigation district. It indicated that water balance models were able to simulate ET for the main crops in the study area.

(a)

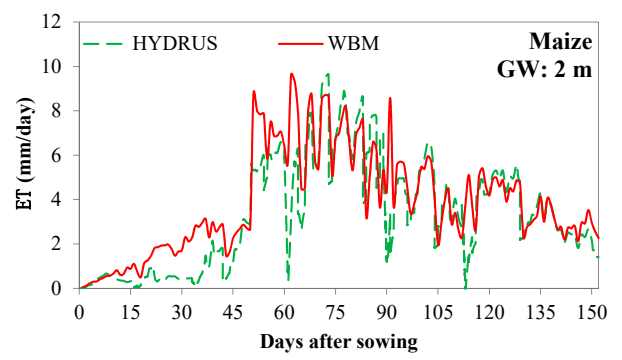

(f)

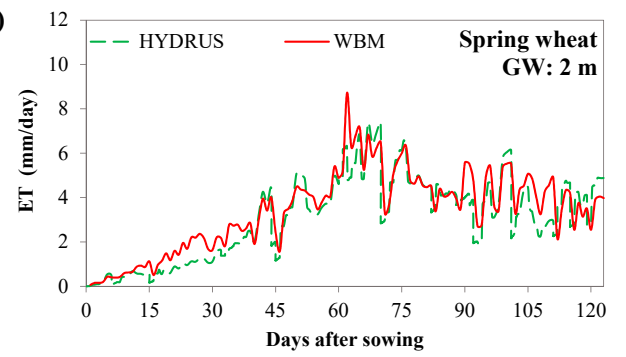

Figure 5. Cont. 
(b)

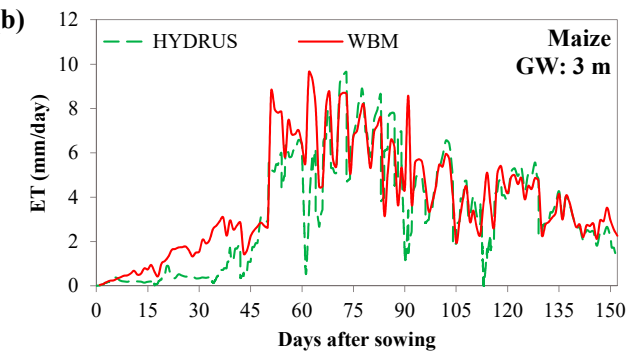

(c)

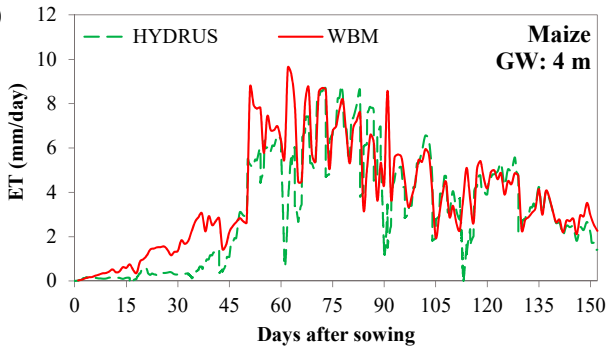

(d)

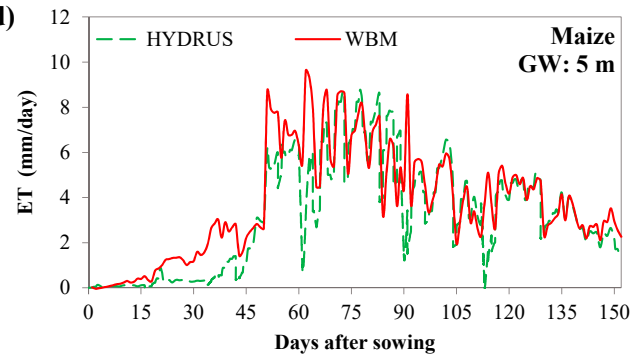

(e)

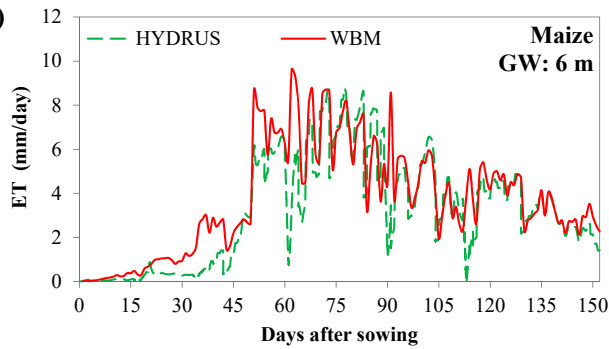

(g)

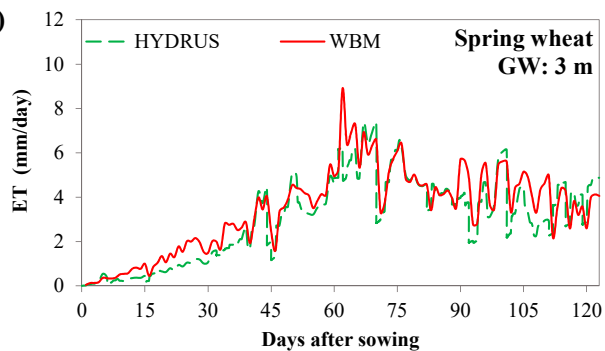

(h)

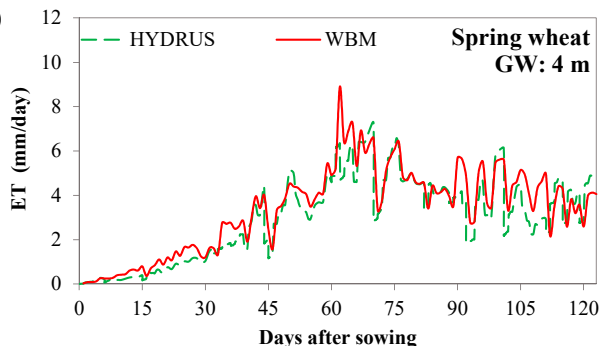

(i)

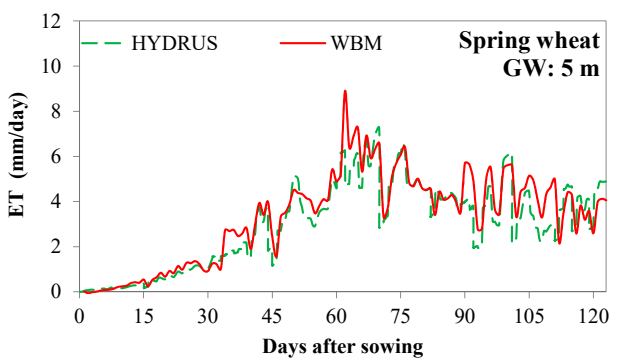

(j)

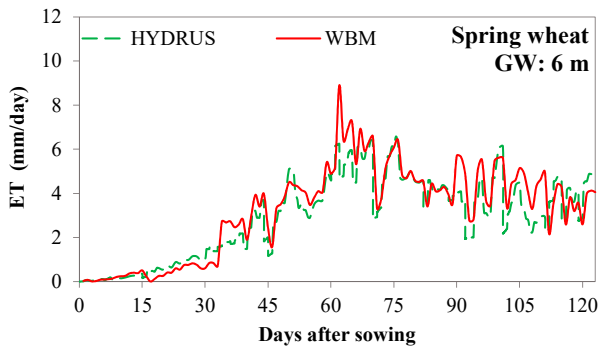

Figure 5. Results of evapotranspiration (ET) for summer maize under the conditions of groundwater depths at $2 \mathrm{~m} \mathrm{(a),} 3 \mathrm{~m} \mathrm{(b)}, 4 \mathrm{~m}(\mathbf{c}), 5 \mathrm{~m}(\mathrm{~d})$ and $6 \mathrm{~m}(\mathbf{e})$, and for spring wheat under the conditions of groundwater depths at $2 \mathrm{~m}(\mathrm{f}), 3 \mathrm{~m} \mathrm{(g)}, 4 \mathrm{~m}(\mathbf{h}), 5 \mathrm{~m}(\mathbf{i})$ and $6 \mathrm{~m}(\mathbf{j})$ (GW means groundwater depth and WBM means water balance model).

Table 5. Results of evapotranspiration, deep percolation and groundwater recharge under different groundwater depths calculated by water balance model and HYDRUS-1D (unit: mm/growing season).

\begin{tabular}{cccccccc}
\hline \multirow{2}{*}{ Component } & \multirow{2}{*}{ Crops } & \multirow{2}{*}{ Model } & \multicolumn{4}{c}{ Groundwater Depth } \\
\cline { 3 - 7 } & & & $\mathbf{2} \mathbf{~ m}$ & $\mathbf{3} \mathbf{~ m}$ & $\mathbf{4} \mathbf{~ m}$ & $\mathbf{5} \mathbf{~ m}$ & $\mathbf{6} \mathbf{~ m}$ \\
\hline \multirow{3}{*}{ Evapotranspiration } & \multirow{2}{*}{ Maize } & Water balance model & 591 & 586 & 581 & 574 & 569 \\
& & HYDRUS-1D & 578 & 574 & 572 & 571 & 570 \\
\cline { 3 - 7 } & \multirow{2}{*}{ Spring wheat } & Water balance model & 422 & 424 & 417 & 409 & 401 \\
& & HYDRUS-1D & 439 & 435 & 433 & 432 & 431 \\
\hline
\end{tabular}


Table 5. Cont

\begin{tabular}{cccccccc}
\hline \multirow{2}{*}{ Component } & \multirow{2}{*}{ Crops } & \multirow{2}{*}{ Model } & \multicolumn{4}{c}{ Groundwater Depth } \\
\cline { 3 - 7 } & & & $\mathbf{2} \mathbf{~ m}$ & $\mathbf{3} \mathbf{~ m}$ & $\mathbf{4} \mathbf{~ m}$ & $\mathbf{5} \mathbf{~ m}$ & $\mathbf{6} \mathbf{~ m}$ \\
\hline \multirow{3}{*}{ Deep percolation } & \multirow{2}{*}{ Maize } & Water balance model & 406 & 374 & 360 & 354 & 350 \\
& & HYDRUS-1D & 417 & 385 & 366 & 357 & 349 \\
\cline { 3 - 7 } & \multirow{2}{*}{ Spring wheat } & Water balance model & 155 & 119 & 107 & 103 & 102 \\
& \multirow{2}{*}{ Maize } & HYDRUS-1D & 138 & 105 & 89 & 78 & 70 \\
\hline \multirow{3}{*}{ Groundwater recharge } & Water balance model & 428 & 326 & 182 & 27 & 0 \\
& & HYDRUS-1D & 417 & 312 & 158 & 4 & 0 \\
\cline { 3 - 7 } & \multirow{2}{*}{ Spring wheat } & Water balance model & 164 & 63 & 0 & 0 & 0 \\
& & HYDRUS-1D & 133 & 28 & 0 & 0 & 0 \\
\hline
\end{tabular}

\subsubsection{Deep Percolation}

The fluctuation trends of deep percolation from root zone to buffer zone calculated by these two models are similar (see Figure 4). Before irrigation, soil water in the root zone was small and water in the buffer zone would flow upwards to the root zone. After irrigation, water in the root zone would seep to the buffer zone immediately. The total volume of deep percolation during the crop-growing period declined with the increase of groundwater depths (Table 5). It was within the range of $349 \mathrm{~mm}$ to $417 \mathrm{~mm}$ calculated by HYDRUS-1D and from $350 \mathrm{~mm}$ to $406 \mathrm{~mm}$ simulated by water balance model for maize. In the zone with shallow groundwater depth, results for maize simulated by HYDRUS-1D were larger than those calculated by water balance model. With the increase of groundwater depth, deep percolation calculated by these two models becomes closer. As for spring wheat, each peak value after irrigation simulated by HYDRUS-1D was smaller than that by the water balance model, which resulted in larger total deep percolation by water balance model than that by HYDRUS-1D model. It was in the range of $70 \mathrm{~mm}$ to $138 \mathrm{~mm}$ calculated by HYDRUS-1D and $102 \mathrm{~mm}$ to $155 \mathrm{~mm}$ simulated by water balance model for spring wheat.

\subsubsection{Groundwater Recharge}

Results of groundwater recharge calculated by the water balance model were larger than those simulated by HYDRUS-1D (shown in Figure 4 and Table 5). The reason was that the upward water flow from groundwater to the vadose zone (i.e., phreatic evaporation) was ignored in the water balance model. In HYDRUS-1D, the lower boundary was set as constant pressure head of $0 \mathrm{~m}$. Under this condition, there would be phreatic evaporation from groundwater to root zone especially before irrigation when the water storage in the vadose zone was low. For this reason, the cumulated groundwater recharge by HYDRUS-1D was less than that by the water balance model. However the difference of recharge results between these two models were in the range of $12 \mathrm{~mm}$ to $35 \mathrm{~mm}$, which is less than $7 \%$ of the total water input in farmland. It confirmed the previous study by Gao et al. $[77,78]$ that during the growing season, upward flux was only a small percentage of overall flux. It indicated that water balance model was capable of simulating groundwater recharge of the main crops in the study area.

Groundwater recharge of the main crops declined with the increase of groundwater depth The results calculated by the water balance model shows that there would be water recharge to the groundwater after irrigation, which was consistent with previous studies that excess precipitation and irrigation would recharge to aquifers [62]. The peak values of groundwater recharge simulated by HYDRUS-1D were smaller than those calculated by water balance model and the fluctuations were milder. For maize, the groundwater recharge was in the range of $4 \mathrm{~mm}$ to $417 \mathrm{~mm}$ simulated by HYDRUS-1D, and $27 \mathrm{~mm}$ to $428 \mathrm{~mm}$ calculated by the water balance model. Under the condition of $6 \mathrm{~m}$ groundwater depth, groundwater recharge was zero for maize. As for spring wheat, groundwater recharge over the growing season was $133 \mathrm{~mm}$ simulated by HYDRUS-1D and $164 \mathrm{~mm}$ calculated 
by the water balance model under the condition of $2 \mathrm{~m}$ groundwater depth. It reduced to $27 \mathrm{~mm}$ (by HYDRUS-1D) and $63 \mathrm{~mm}$ (by water balance model) when the groundwater depth increased to $3 \mathrm{~m}$. Groundwater recharge in the spring wheat was zero when groundwater depth was over $4 \mathrm{~m}$.

Results in this section showed that calculations of soil water storage, evapotranspiration, deep percolation and water recharge from root zone to buffer zone by the water balance model were in reasonable agreement with the results simulated by HYDRUS-1D, which indicated that water balance models were capable of being used to predict soil water balance under various conditions.

\subsection{Soil Water Balance under Different Groundwater Depths}

Results of soil water balance in the root zone under loam texture for each cropland unit calculated by water balance models are shown in Figure 6. Evapotranspiration for maize was not sensitive to the variation of groundwater depths. The water input (irrigation plus precipitation) in the maize field was $965 \mathrm{~mm}$ and around $60 \%$ of it was consumed by evapotranspiration. Meanwhile, for spring wheat, evapotranspiration decreased with the increase of groundwater depth. Under the condition of $2 \mathrm{~m}$ groundwater depth, evapotranspiration accounted for $75 \%$ of the total water input $(564 \mathrm{~mm})$. When groundwater depth was $6 \mathrm{~m}$, the ratio declined to $71 \%$. The volume of water transfer from root zone to buffer zone decreased with the increase of groundwater depth for both maize and spring wheat. The proportion of water recharge from root zone to buffer zone on the total water input ranged from 36 to $42 \%$ for maize. In the spring wheat field, the proportion of water recharge from root zone to buffer zone would decrease from 27 to $18 \%$ with the groundwater depth increased from $2 \mathrm{~m}$ to $6 \mathrm{~m}$. Under the current irrigation schedules, water use efficiency of spring wheat was more effective than maize.

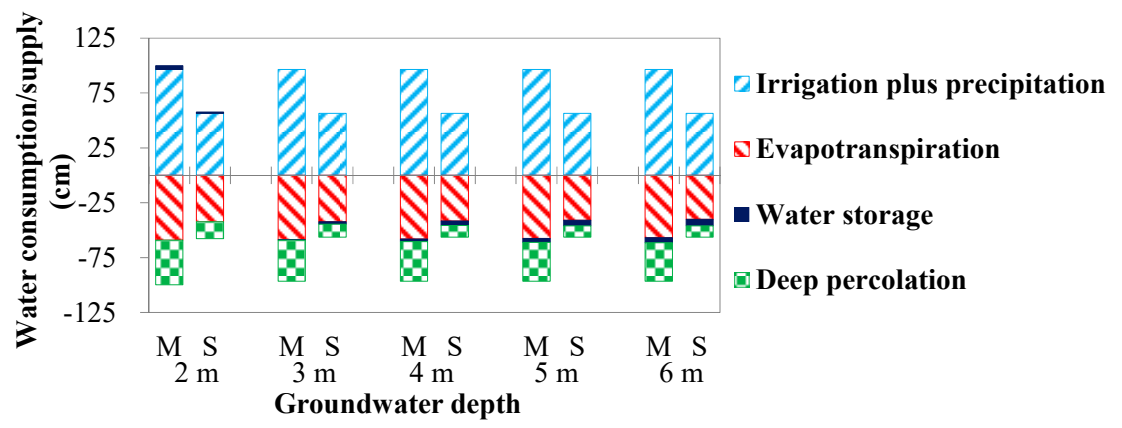

Figure 6. Soil water consumption and supply in root zone (positive means supply, negative means consumption, $\mathrm{M}$ means maize and $\mathrm{S}$ means spring wheat).

Figure 7a shows results of the water budget in the buffer zone for main crops in the study area. Terms of the water budget in the buffer zone illustrated large differences when groundwater depth changed. When groundwater depth was less than $3 \mathrm{~m}$, water storage in the buffer zone would decrease and water from the root zone would continue seeping to groundwater (i.e., deep percolation). When groundwater depth becomes deeper, water discharged from the root zone would stay in the buffer zone and lead to less deep percolation. In the maize field, over $80 \%$ of the water discharged from the root zone would seep into groundwater directly when groundwater depth was $3 \mathrm{~m}$. When groundwater depth was $4 \mathrm{~m}$ or $5 \mathrm{~m}$, there would be $50 \%$ or $7 \%$ of the water discharged from the root zone seeping into groundwater. When groundwater increased to $6 \mathrm{~m}$, all of the water discharged from the root zone would stay in the buffer zone. In the spring wheat field, all the water discharged from the root zone would stay in the buffer zone when groundwater depth was over $3 \mathrm{~m}$. Note that in this study (as shown in Figure 7a) we assumed the initial soil water of farmland was at the hydrostatic condition after a long period of laying fallow through the winter. For some places there might be flood irrigation (e.g., fall irrigation and winter irrigation in the late autumn period) to leach salts and to restore water for springtime. Under those conditions, the initial soil water content 
might be much larger than the assumption in Figure 7a. We assumed under this condition that soil water in the buffer zone was at field capacity when crop was planted. Thus, results showed that deep percolation from root zone to buffer zone was nearly equal for various groundwater depths (Figure $7 \mathrm{~b}$ ). Almost all the deep percolation would enter groundwater, which was different from results under hydrostatic condition.

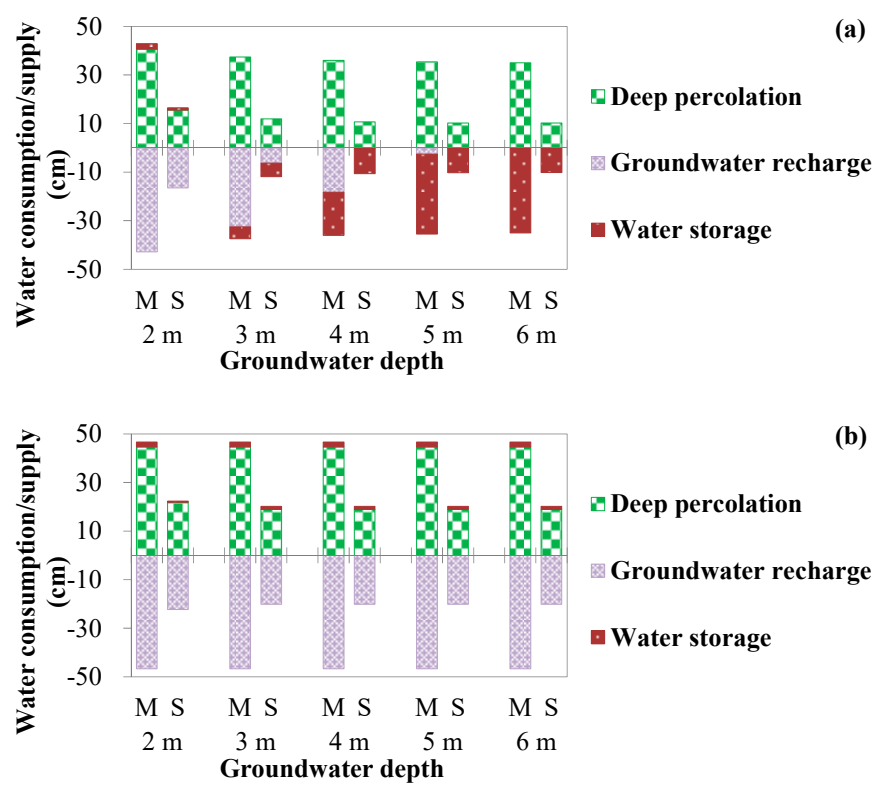

Figure 7. Soil water consumption and supply in buffer zone with the initial condition of (a) hydrostatic condition and (b) harvest condition (positive means supply, negative means consumption, M means maize and $\mathrm{S}$ means spring wheat).

\subsection{Soil Water Balance under Various Irrigation Depths}

In the arid area, crop productivity would be influenced greatly by soil water stress in the root zone because of less irrigation and high evapotranspiration. While there was inappropriate irrigation, such as excessive irrigation, in some places, some of the irrigated water would be consumed by soil evaporation, or percolate to groundwater and result in the waste of valuable water resources and possibly fertilizer and pesticides. Therefore it is necessary to study soil water movement and water balance in the vadose zone under different irrigation schedules with various irrigation depths. In this section, components of the soil water balance in loam under different conditions were simulated using water balance models. Results of evapotranspiration, variation of soil water storage in the vadose zone and groundwater recharge for maize and spring wheat are shown in Figure 8.
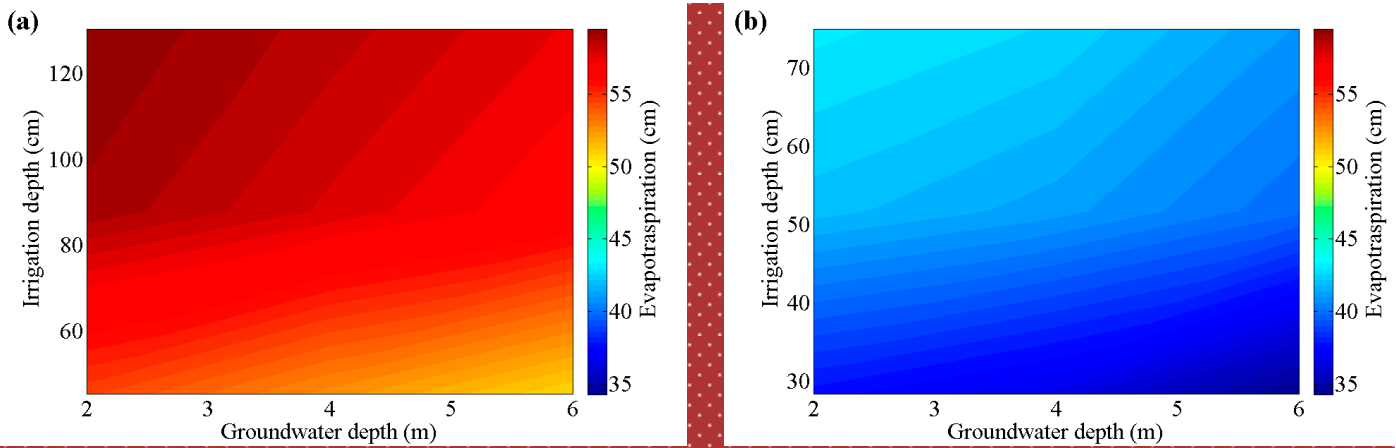

Figure 8. Cont. 
(c)

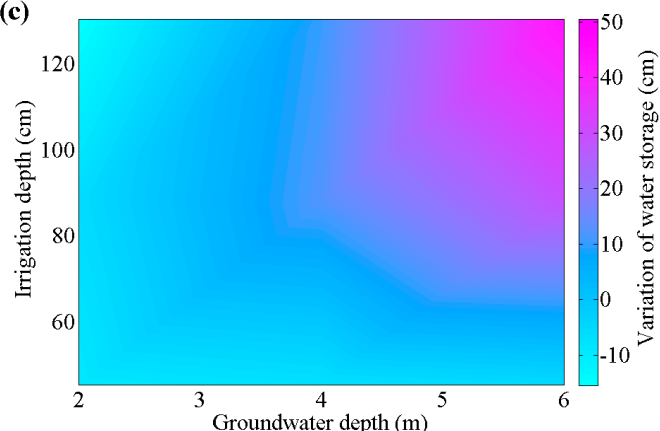

(e)

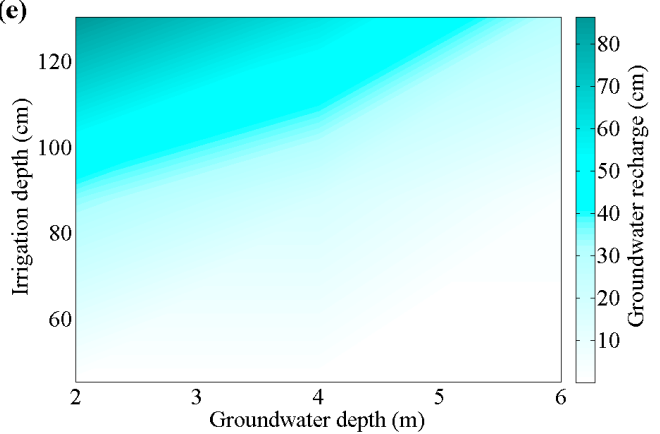

(d)

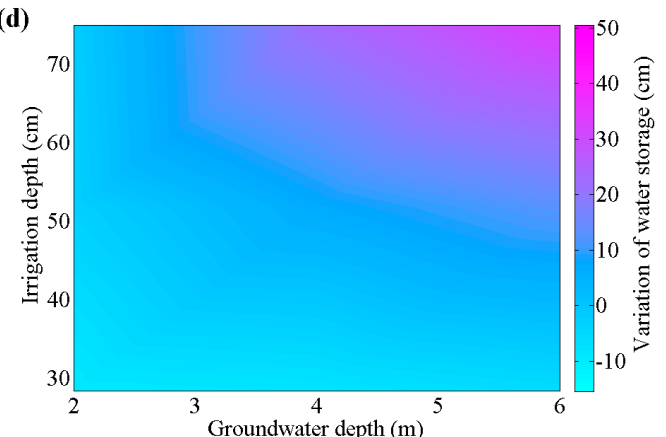

(f)

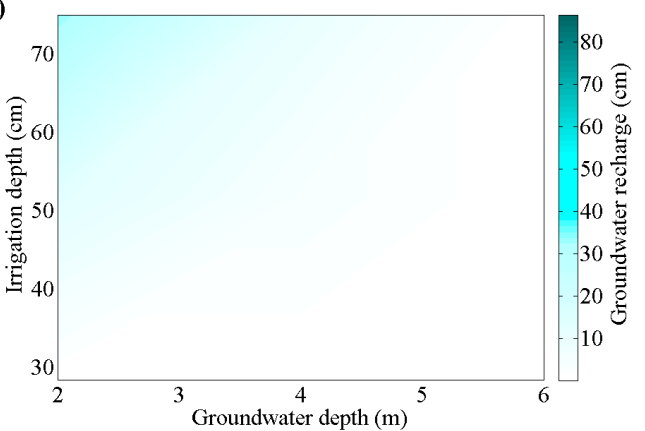

Figure 8. Results of evapotranspiration for maize (a) and spring wheat (b), variation of soil water storage in vadose zone for maize (c) and spring wheat (d), and groundwater recharge for maize (e) and spring wheat (f) in different irrigation quota under various groundwater depths.

Evapotranspiration of maize was larger than that of spring wheat, and evapotranspiration increased with the increase of irrigation amount for the same groundwater depth (Figure 8a,b). Evapotranspiration had a greater dependence on the amount of water applied when groundwater was near $6 \mathrm{~m}$ depth than when groundwater was shallow. For example, reducing the irrigation depth by $60 \%$, evapotranspiration for maize decreased by $8 \%$ when groundwater depth was $2-3 \mathrm{~m}, 9 \%$ at $4 \mathrm{~m}$ groundwater depth and $10 \%$ at 5-6 m. When irrigation application was reduced to $80 \%$ in the maize field, evapotranspiration would decrease by $2 \%$ under all the groundwater depths. When irrigation increased by $20 \%$ or $40 \%$, evapotranspiration of maize would increase by $0.5 \%$ to $0.6 \%$ for groundwater depths of $2 \mathrm{~m}$ and $0.7 \%$ to $0.9 \%$ for a groundwater table between 5 and $6 \mathrm{~m}$. For spring wheat, evapotranspiration would decrease by $4 \%$ to $6 \%$ when irrigation water application was decreased by $20 \%$ to $40 \%$ and it would increase by $1 \%$ to $2 \%$ when irrigation water application was increased to $120 \%$ to $140 \%$.

Soil water storage would decrease (negative values) when groundwater was deep with deficit irrigation (Figure $8 \mathrm{c}, \mathrm{d}$ ). In general, soil water storage tended to increase during the growing season when irrigation amounts were high and groundwater was deep with thick buffer zone.

Groundwater recharge would increase with the decrease of groundwater depth and the increase of the irrigation water applications (Figure 8e,f). Under the same groundwater depths, groundwater recharge of maize was larger than that of spring wheat.

3.4. Soil Water Balance in the Major Cropland under Water Saving Irrigation Practices in the Middle Reaches of Heihe River Basin

Results of evapotranspiration, variation of soil water storage and groundwater recharge simulated by the water balance model in the major cropland (covering $1275 \mathrm{~km}^{2}$ ) in the middle reaches of Heihe River Basin are shown in

Figure 9 shows that evapotranspiration in the north (e.g., Anyang Irrigation District and Huazhai Irrigation District) was less than that in other irrigation districts under the same scenario. With the implementation of water-saving irrigation practices, evapotranspiration decreased with the reduction 
of irrigation water application, especially in the middle of the study area, such as in the Liyuanhe Irrigation District. Under the status quo, the total evapotranspiration of farmland cultivated with maize and spring wheat in the study area was $7.06 \times 10^{8} \mathrm{~m}^{3}$; it would slightly decrease by $2 \%$ and $5 \%$ when the irrigation quota cut down to $80 \%$ and $60 \%$, respectively. Groundwater recharge in most cropped fields was less than $30 \mathrm{~mm}$. Under the status quo, the recharge in some places in the north and middle of the study area (e.g., the Shahe Irrigation district and the Liyuanhe Irrigation District) was greater than $450 \mathrm{~mm}$. The total amount of groundwater recharge of the main crops reduced with the decrease of irrigation quotas. It would decrease from $1.68 \times 10^{8} \mathrm{~m}^{3}$ in status quo, to $1.0^{3} \times 10^{8} \mathrm{~m}^{3}$ and $4.75 \times 10^{8} \mathrm{~m}^{3}$ under Scenario A and Scenario B. Under the status quo, excessive irrigation would lead to the increase of soil water storage in the vadose zone $\left(2.89 \times 10^{8} \mathrm{~m}^{3}\right)$, when irrigation amount reduced to $80 \%$ or $60 \%$, the volumes would be decreased by $43 \%$ and $86 \%$, respectively. Figure 9 .
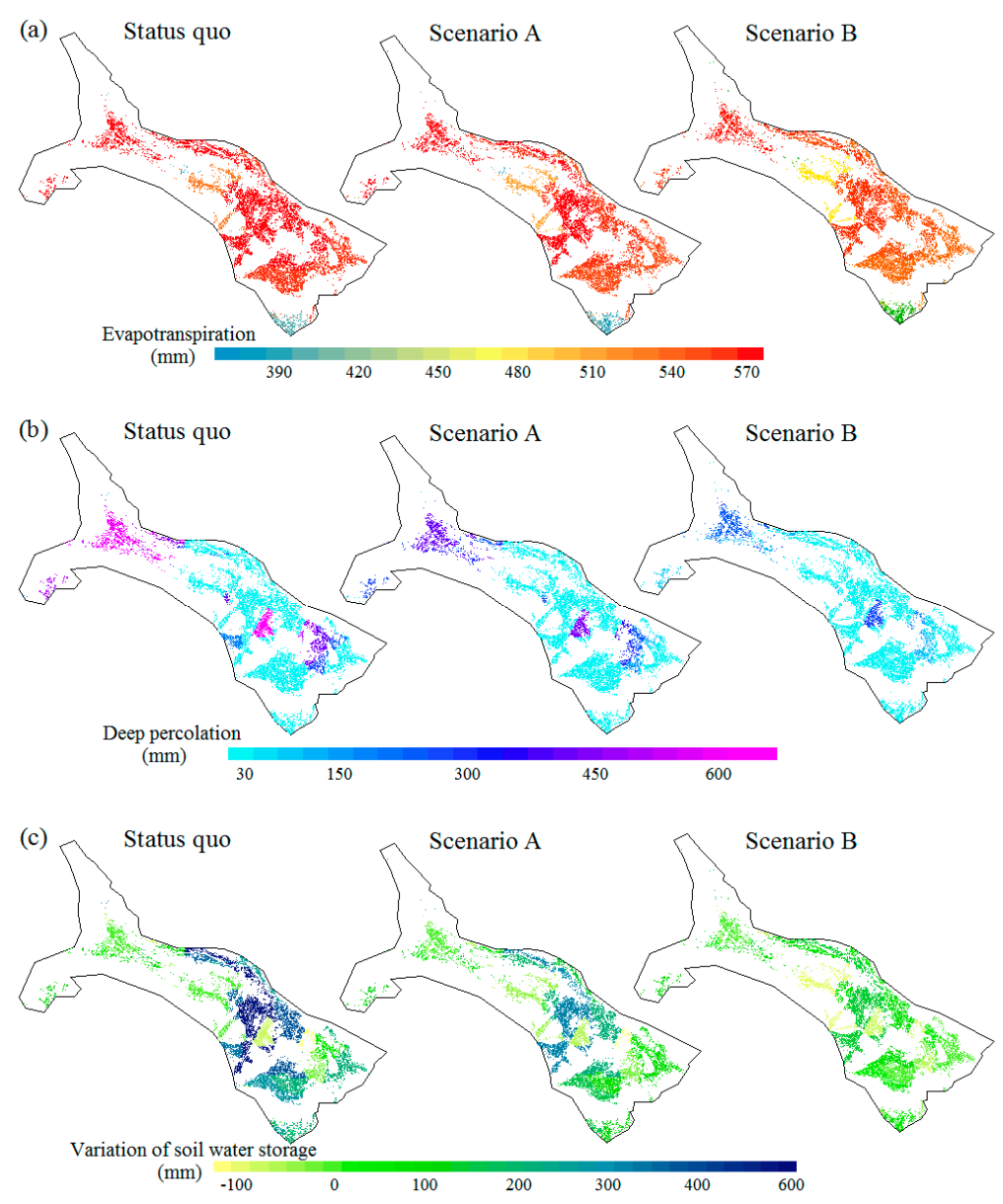

Figure 9. Results of evapotranspiration (a), groundwater recharge (b) and variation of soil water storage in vadose zone (c) in the farmland cultivated with maize and spring wheat of study area under different water saving irrigation practice scenarios.

\section{Conclusions}

To study the soil water balance in farmland of the middle reaches of the Heihe River Basin, we proposed a corresponding soil water balance model and the simulation results were compared with the results calculated by the hydrodynamic model HYDRUS-1D. Then, components of soil water balance under different conditions of groundwater depths and irrigation quotas during the growing season of main crops were analyzed using corresponding water balance models. With pre/post-processing by ArcGIS, the water balance models were further applied for predicting the spatial distribution of evapotranspiration, groundwater recharge and variation of soil water storage in 
farmland of the whole middle reaches under different water-saving irrigation practice scenarios. Conclusions are drawn as follows:

(1) A good coherence was shown between the simulated results of the water balance models and HYDRUS-1D model in soil water storage, evapotranspiration, deep percolation from the root zone and groundwater recharge, indicating that the water balance models were suitable to simulate soil water movement in the vadose zone cultivated with maize or spring wheat in the study area.

(2) Results of simulations under different groundwater depths showed that components of soil water balance in the root zone for maize was not sensitive to the variation of groundwater depths. Meanwhile, for spring wheat, the volume of evapotranspiration was decreased with the increase of groundwater depth. More water deep percolation from the root zone would stay in the buffer zone and led to less groundwater recharge when groundwater depth was larger. When groundwater depth reached $3 \mathrm{~m}$ for spring wheat and $6 \mathrm{~m}$ for maize, groundwater recharge from farmland to aquifer was negligible.

(3) Results of simulations under different irrigation quotas with various groundwater depths showed that evapotranspiration of the main crops in the study area would be more prominently influenced by irrigation quota under deep groundwater depth than that under shallow groundwater depth. Groundwater recharge of farmland would increase with the increase of the irrigation quota.

(4) Results of scenario simulations under different water-saving irrigation practices showed that groundwater recharge in farmland cultivated with maize and spring wheat would sharply decrease with the implementation of deficit irrigation. Evapotranspiration of the main crops in the study area would be slightly reduced under deficit irrigation.

Note that the proposed soil water balance model is validated by HYDRUS-1D. Generally speaking it is insufficient to validate one proposed model by the other model without calibrations. Despite the fact that HYDRUS-1D is a popular model and has been successfully used in previous research in this region, to ensure our study results more sound and reliable, data regarding regional soil water balance need to be collected or monitored to further validate the models.

Acknowledgments: This work was supported by Projects of National Natural Science Foundation of China (Grant No. 91425302, 51379207) and the Program of Introducing Talents of Discipline to Universities (B14002).

Author Contributions: J.L. and X.M. designed the study; J.L. did the simulations and analyzed the data; J.L. and X.M. wrote the paper; S.S. and T.S.S. contributed to the model design and discussed the results.

Conflicts of Interest: The authors declare no conflict of interest.

\section{References}

1. Mermoud, A.; Tamini, T.; Yacouba, H. Impacts of different irrigation schedules on the water balance components of an onion crop in a semi-arid zone. Agric. Water Manag. 2005, 77, 282-295. [CrossRef]

2. Igbadun, H.; Salim, B.; Tarimo, A.; Mahoo, H. Effects of deficit irrigation scheduling on yields and soil water balance of irrigated maize. Irrig. Sci. 2008, 27, 11-23. [CrossRef]

3. Perea, R.; Poyato, E.; Montesinos, P.; Rodriguez Diaz, J. Optimization of irrigation scheduling using soil Water balance and genetic algorithms. Water Resour. Manag. 2016, 30, 2815-2830. [CrossRef]

4. Hochmuth, H.; Thevs, N.; He, P. Water allocation and water consumption of irrigation agriculture and natural vegetation in the Heihe River watershed, NW China. Environ. Earth Sci. 2015, 73, 5269-5279. [CrossRef]

5. Wu, X.; Zhou, J.; Wang, H.; Li, Y.; Zhong, B. Evaluation of irrigation water use efficiency using remote sensing in the middle reach of the Heihe river, in the semi-arid Northwestern China. Hydrol. Process. 2015, 29, 2243-2257. [CrossRef]

6. Zhao, L.; Zhao, W. Water balance and migration for maize in an oasis farmland of northwest China. Chin. Sci. Bull. 2014, 59, 4829-4837. [CrossRef]

7. Li, J.; Wang, X.; Bai, L.; Mao, X. Quantification of lateral seepage from farmland during maize growing season in arid region. Agric. Water Manag. 2017, 191, 85-97. [CrossRef] 
8. Zhang, S.; Yang, X.; Lovdahl, L. Soil management practice effect on water balance of a dryland soil during fallow period on the Loess Plateau of China. Soil Water Res. 2016, 11, 64-73. [CrossRef]

9. Zhang, D.; Yao, P.; Na, Z.; Cao, W.; Zhang, S.; Li, Y.; Gao, Y. Soil Water balance and water use efficiency of dryland wheat in different precipitation years in response to green manure approach. Sci. Rep. 2016, 6, 1-12. [CrossRef] [PubMed]

10. Sun, H.; Liu, C.; Zhang, X.; Shen, Y.; Zhang, Y. Effects of irrigation on water balance, yield and WUE of winter wheat in the North China Plain. Agric. Water Manag. 2006, 85, 211-218. [CrossRef]

11. Lei, Z.; Yang, S.; Xie, S. Fixed plane flux method and its application to soil water balance. J. Hydraul. Eng. 1988, 5, 1-7. (In Chinese)

12. Wen, Y.; Yang, J.; Shang, S. Analysis on evapotranspiration and water balance of cropland with plastic mulch in arid region using dual crop coefficient approach. Trans. CSAE 2017, 33, 138-147. (In Chinese)

13. Chen, Z. Soil water balance measurement in field scale. Pedosphere 1992, 2, 115-124.

14. Yang, J.; Li, B.; Liu, S. A large weighing lysimeter for evapotranspiration and soil-water-Groundwater exchange studies. Hydrol. Process. 2000, 14, 1887-1897. [CrossRef]

15. Aouade, G.; Ezzahar, J.; Amenzou, N.; Er-Raki, S.; Benkaddour, A.; Khabba, S.; Jarlan, L. Combining stable isotopes, Eddy Covariance system and meteorological measurements for partitioning evapotranspiration, of winter wheat, into soil evaporation and plant transpiration in a semi-arid region. Agric. Water Manag. 2016, 177, 181-192. [CrossRef]

16. Malek, E.; Bingham, G.E. Comparison of the Bowen ratio-energy balance and the water balance methods for the measurement of evapotranspiration. J. Hydrol. 1993, 146, 167-178. [CrossRef]

17. Cheng, L.; Liu, W.; Li, Z.; Han, X. Land use change affects groundwater recharge in the Changwu Loess Tableland of China. Adv. Water Sci. 2016, 27, 670-678. (in Chinese)

18. Evett, S.R.; Schwartz, R.C.; Casanova, J.J.; Heng, L. Soil water sensing for water balance, ET and WUE. Agric. Water Manag. 2012, 104, 1-9. [CrossRef]

19. Shang, S.; Mao, X. A physicoempirical model for soil water simulation in crop root zone. Pedosphere 2011, 21, 512-521. [CrossRef]

20. Li, Y.; Šimůnek, J.; Jing, L.; Zhang, Z.; Ni, L. Evaluation of water movement and water losses in a direct-seeded-rice field experiment using Hydrus-1D. Agric. Water Manag. 2014, 142, 38-46. [CrossRef]

21. Shang, S.; Mao, X. A two-parameter exponential recession model for simulating cropland soil moisture dynamics. Chin. Geogr. Sci. 2014, 24, 575-586. [CrossRef]

22. Han, M.; Zhao, C.; Šimůnek, J.; Feng, G. Evaluating the impact of groundwater on cotton growth and root zone water balance using Hydrus-1D coupled with a crop growth model. Agric. Water Manag. 2015, 160, 64-75. [CrossRef]

23. Li, Y.; Šimůnek, J.; Wang, S.; Yuan, J.; Zhang, W. Modeling of soil water regime and water balance in a transplanted rice field experiment with reduced irrigation. Water 2017, 9, 1-14. [CrossRef]

24. Iqbal, S.; Guber, A.K.; Khan, H. Estimating nitrogen leaching losses after compost application in furrow irrigated soils of Pakistan using HYDRUS-2D software. Agric. Water Manag. 2016, 168, 85-95. [CrossRef]

25. Shang, S.; Mao, X.; Lei, Z.; Yang, S. Soil Water Simulation Models with Applications; Science Press: Beijing, China, 2009. (In Chinese)

26. Ranatunga, K.; Nation, E.; Barratt, D. Review of soil water models and their applications in Australia. Environ. Model. Softw. 2008, 23, 1182-1206. [CrossRef]

27. Ji, X.; Kang, E.; Chen, R.; Zhao, W.; Zhang, Z.; Jin, B. A mathematical model for simulating water balances in cropped sandy soil with conventional flood irrigation applied. Agric. Water Manag. 2007, 87, 337-346. [CrossRef]

28. Yadav, B.K.; Mathur, S.; Siebel, M.A. Soil moisture dynamics modeling considering the root compensation mechanism for water uptake by plants. J. Hydrol. Eng. 2009, 14, 913-922. [CrossRef]

29. Šimůnek, J.; Šejna, M.; Saito, H.; Sakai, M.; van Genuchten, M.T. The HYDRUS-1D Software Package for Simulating the Movement Of Water, Heat, and Multiple Solutes in Variably Saturated Media; Version 4.0; HYDRUS Software Series 3; Department of Environmental Sciences, University of California Riverside: Riverside, CA, USA, 2008; p. 315.

30. Tan, X.; Shao, D.; Liu, H. Simulating soil water regime in lowland paddy fields under different water managements using HYDRUS-1D. Agric. Water Manag. 2014, 132, 69-78. [CrossRef] 
31. Shang, S.; Mao, X. Application of a simulation based optimization model for winter wheat irrigation scheduling in North China. Agric. Water Manag. 2006, 85, 314-322. [CrossRef]

32. Nishat, S.; Guo, Y.; Baetz, B.W. Development of a simplified continuous simulation model for investigating long-term soil moisture fluctuations. Agric. Water Manag. 2007, 92, 53-63. [CrossRef]

33. Panigrahi, B.; Panda, S.N. Field test of a soil water balance simulation model. Agric. Water Manag. 2003, 58, 223-240. [CrossRef]

34. Kendy, E.; G Rard-Marchant, P.; Todd Walter, M.; Zhang, Y.; Liu, C.; Steenhuis, T.S. A soil-water-balance approach to quantify groundwater recharge from irrigated cropland in the North China Plain. Hydrol. Process. 2003, 17, 2011-2031. [CrossRef]

35. Kendy, E.; Zhang, Y.; Liu, C.; Wang, J.; Steenhuis, T. Groundwater recharge from irrigated cropland in the North China Plain: Case study of Luancheng County, Hebei Province, 1949-2000. Hydrol. Process. 2004, 18, 2289-2302. [CrossRef]

36. Han, M.; Zhao, C.; Feng, G.; Yan, Y.; Sheng, Y. Evaluating the effects of mulch and irrigation amount on soil water distribution and root zone water balance using HYDRUS-2D. Water 2015, 7, 2622-2640. [CrossRef]

37. Talebnejad, R.; Sepaskhah, A.R. Effect of deficit irrigation and different saline groundwater depths on yield and water productivity of quinoa. Agric. Water Manag. 2015, 159, 225-238. [CrossRef]

38. Arnold, J.G.; Allen, P.M.; Bernhardt, G. A comprehensive surface-groundwater flow model. J. Hydrol. 1993, 142, 47-69. [CrossRef]

39. Xu, X.; Huang, G.; Zhan, H.; Qu, Z.; Huang, Q. Integration of SWAP and MODFLOW-2000 for modeling groundwater dynamics in shallow water table areas. J. Hydrol. 2012, 412-413, 170-181. [CrossRef]

40. Twarakavi, N.K.C.; Šimůnek, J.; Seo, S. Evaluating interactions between groundwater and vadose zone using the HYDRUS-based flow package for MODFLOW. Vadose Zone J. 2008, 7, 757-768. [CrossRef]

41. Lebon, E.; Dumas, V.; Pieri, P.; Schultz, H.R. Modeling the seasonal dynamics of the soil water balance of vineyards. Funct. Plant Biol. 2003, 30, 699-710. [CrossRef]

42. Suleiman, A.A. Modeling daily soil water dynamics during vertical drainage using the incoming flow concept. Catena 2008, 73, 312-320. [CrossRef]

43. Chen, H.; Huang, J.; Wu, J.; Yang, J. Soil water balance model in root zone of winter wheat based on system dynamics. Trans. CSAE 2010, 26, 21-28. (In Chinese)

44. Byrne, C.F.; Stormont, J.C.; Stone, M.C. Soil water balance dynamics on reclaimed mine land in the southwestern United States. J. Arid Environ. 2017, 136, 28-37. [CrossRef]

45. Wang, X.; Wang, X.; Jia, F.; Xu, Z. Application of Thornthwaite and Mather water balance model in runoff yield calculation at watershed scale. Bull. Soil Water Conserv. 2015, 35, 193-198. (In Chinese)

46. Portoghese, I.; Uricchio, V.; Vurro, M. A GIS tool for hydrogeological water balance evaluation on a regional scale in semi-arid environments. Comput. Geosci. 2005, 31, 15-27. [CrossRef]

47. Tilahun, K.; Merkel, B. Estimation of groundwater recharge using a GIS-based distributed water balance model in Dire Dawa, Ethiopia. Hydrogeol. J. 2009, 17, 1443-1457. [CrossRef]

48. Li, J.; Mao, X.; Kang, S.; Barry, D.A. Modeling of hydrological processes in arid agricultural regions. Front. Agric. Sci. Eng. 2015, 2, 283-294. [CrossRef]

49. Sun, Q.; Wu, P.; Wang, Y.; Zhao, X. Health volume of agricultural water consumption and its calculation model in the Heihe River Basin. Chin. J. Eco-Agric. 2012, 20, 181-188. (In Chinese) [CrossRef]

50. The Ministry of Water Resources of the People's Republic of China. Near-Future Plan for Water Treatment of Heihe River Basin; The Ministry of Water Resources of the People's Republic of China: Beijing, China, 2001.

51. Li, J.; Mao, X.; Li, M. Modeling hydrological processes in oasis of Heihe River Basin by landscape unit-based conceptual models integrated with FEFLOW and GIS. Agric. Water Manag. 2017, 179, 338-351. [CrossRef]

52. Peranginangin, N.; Sakthivadivel, R.; Scott, N.R.; Kendy, E.; Steenhuis, T.S. Water accounting for conjunctive groundwater/surface water management: Case of the Singkarak-Ombilin River basin, Indonesia. J. Hydrol. 2004, 292, 1-22. [CrossRef]

53. Wang, Y.; Li, S.; Wang, W.; Sun, X.; Han, N. Simulation of dynamic soil moisture of winter wheat based on conceptual model. Meteorol. Mon. 2010, 36, 102-108. (In Chinese)

54. Wang, Y. Study of the Transformation of Water in the Field Water Production Function for Winter Wheat. Ph.D. Thesis, Tsinghua University, Beijing, China, 1996.

55. Cong, Z.; Lü, H.; Ni, G. A simplified dynamic method for field capacity estimation and its parameter analysis. Water Sci. Eng. 2014, 7, 351-362. 
56. Mao, X. A Study of Water and Heat Transfer in Groundwater-Soil-Plant-Atmosphere System in the Oasis of Arid Area. Ph.D. Thesis, Tsinghua University, Beijing, China, 1998.

57. Allen, R.G.; Pereira, L.S.; Raes, D.; Smith, M. Crop evapotranspiration-Guidelines for computing crop water requirements. In FAO Irrigation and Drainage, Paper 56; FAO: Rome, Italy, 1998.

58. Li, J.; Yang, X.; Cao, S.; Ma, Z.; Xiao, J.; Chen, F.; Li, Y.; Qiu, J.; Feng, H.; Chen, T. Water requirement and crop coefficient of different planting patterns in Zhangye Area of Gansu Province. Acta Agric. Jiangxi 2009, 21, 17-20. (In Chinese)

59. Lei, Z.; Yang, S.; Xie, S. Soil Hydrodynamics; Tsinghua University Press: Beijing, China, 1988.

60. Guo, Y. Irrigation and Drainage Engineering; China Water and Power Press: Beijing, China, 1997. (In Chinese)

61. Zhang, S.; Kang, S.; Lui, X.; Xiong, Y.Z. A study on the variation laws of field phreatic water evaporation and its calculation method. Water Resour. Water Eng. 1995, 6, 9-15. (In Chinese)

62. Yang, X.; Chen, Y.; Pacenka, S.; Gao, W.; Zhang, M.; Sui, P.; Steenhuis, T.S. Recharge and groundwater use in the North China Plain for six irrigated crops for an eleven year period. PLoS ONE 2015, e0115269. [CrossRef] [PubMed]

63. Li, D.; Ji, X.; Zhao, L. Simulation of seed corn farmland soil moisture migration regularity in the midstream of the Heihe River Basin. Arid Zone Res. 2015, 32, 467-475. (In Chinese)

64. Xiao, Q.; Huang, M.; Shao, M.; Ren, L. Infiltration and drainage processes of different textural soil moisture in middle reaches of Heihe River Basin. Trans. CSAE 2014, 30, 124-131. (In Chinese)

65. Zhou, J.; Cheng, G.; Li, X.; Hu, B.; Wang, G. Numerical modeling of wheat irrigation using coupled HYDRUS and WOFOST models. Soil Sci. Soc. Am. J. 2012, 76, 648-662. [CrossRef]

66. Li, H.; Yi, J.; Zhang, J.; Zhao, Y.; Si, B.; Hill, R.; Cui, L.; Liu, X. Modeling of soil water and salt dynamics and its effects on root water uptake in Heihe arid wetland, Gansu, China. Water 2015, 7, 2382-2401. [CrossRef]

67. Mualem, Y. A new model for predicting the hydraulic conductivity of unsaturated porous media. Water Resour. Res. 1976, 12, 513-522. [CrossRef]

68. Van Genuchten, M.T. A closed-form equation for predicting the hydraulic conductivity of unsaturated soils. Soil Sci. Soc. Am. J. 1980, 44, 892-898. [CrossRef]

69. Feddes, R.A.; Kowalik, P.J.; Zaradny, H. Simulation of Field Water Use and Crop Yield; Wiley: New York, NY, USA, 1978; Volume 129.

70. Li, S.; Lan, N. Research on Crop Water Requirement and Water Saving Irrigation in Arid Area; Gansu Science and Technoloy Press: Lanzhou, China, 1992; p. 33. (In Chinese)

71. Ritchie, J.T. Model for predicting evaporation from a row crop with incomplete cover. Water Resour. Res. 1972, 8, 1204-1213. [CrossRef]

72. Li, J.; Zhu, T.; Mao, X.; Adeloye, A.J. Modeling crop water consumption and water productivity in the middle reaches of Heihe River Basin. Comput. Electron. Agric. 2016, 123, 242-255. [CrossRef]

73. Wesseling, J.G.; Elbers, J.A.; Kabat, P.; van-den-Broek, B.J. SWATRE: Instructions for Input, Internal Not; Win and Staring Centre: Wageningen, The Netherlands, 1991.

74. Šimůnek, J.; Genuchten, M.T.V.; Šejna, M. Development and applications of the HYDRUS and STANMOD software packages and related codes. Vadose Zone J. 2008, 7, 587-600. [CrossRef]

75. Jiang, X. Characteristics of Water Consumption of Female and Male Parents and Evapotranspiration Modeling of Maize for Seed Production in an Arid Region of Northwest China. Ph.D. Thesis, China Agricultural University, Beijing, China, 2016.

76. Thu, T. The Spatial and Temporal Variation of Crop Water Consumption in the Middle Heihe River Basin. Master's Thesis, China Agricultural University, Beijing, China, 2014.

77. Gao, X.; Bai, Y.; Huo, Z.; Xu, X.; Huang, G.; Xia, Y.; Steenhuis, T.S. Deficit irrigation enhances contribution of shallow groundwater to crop water consumption in arid area. Agric. Water Manag. 2017, 185, 116-125. [CrossRef]

78. Gao, X.; Huo, Z.; Qu, Z.; Xu, X.; Huang, G.; Steenhuis, T.S. Modeling contribution of shallow groundwater to evapotranspiration and yield of maize in an arid area. Sci. Rep. 2017, 7, 1-13. [CrossRef] [PubMed]

(C) 2017 by the authors. Licensee MDPI, Basel, Switzerland. This article is an open access article distributed under the terms and conditions of the Creative Commons Attribution (CC BY) license (http://creativecommons.org/licenses/by/4.0/). 